\title{
Language shift: analysing language use in multilingual classroom interactions
}

\author{
Harni Kartika-Ningsih ${ }^{1,2^{*}}$ (D) and David Rose ${ }^{3}$
}

\author{
* Correspondence: \\ kartika-harni@hotmail.com \\ ${ }^{1}$ Department of Curriculum and \\ Instruction, Faculty of Education, \\ Chinese University of Hong Kong, \\ Ma Liu Shui, Hong Kong \\ ${ }^{2}$ Hong Kong, Hong Kong SAR \\ Full list of author information is \\ available at the end of the article
}

\begin{abstract}
This paper offers a framework and set of tools for analysing the use of language shift in multilingual classroom discourse. The term language shift refers to the use of multiple languages in all types of interactions, including teaching and learning. The analysis was developed in the context of an action research project in Indonesian schools. It includes three components: a framework for mapping teaching approaches in multilingual classrooms; an analysis of pedagogic interactions, showing the structures of language shift within and between speaker roles; and an analysis of the pedagogic functions of language shift, as lessons and teacher/learner interactions unfold. The theoretical foundation for the analysis is the model of language as text-in-context developed in systemic functional linguistics.
\end{abstract}

Keywords: Code-switching, Language shift, Multilingual classrooms, Classroom discourse

\section{Background}

Multilingualism in communities and schools

In multilingual communities, switching from one language to another takes place on a daily basis, so members are likely to speak more than one language. In Indonesia, three major language sectors are part of everyday life for many speakers, including the national language, Bahasa Indonesia, regional languages, such as Javanese or Sundanese, and foreign languages, such as English and Arabic (Sneddon, 2003; Montolalu \& Suryadinata, 2007). A Sundanese speaker, for example, who resides in Bandung, a Sundanese speaking area in West Java, speaks Sundanese with their peers. If a peer speaks Indonesian, Bahasa Indonesia can also be a part in the conversation. Additionally, if both of them speak English, that may also be a part of the conversation.

Author Harni Kartika-Ningsih is an example of such multilingualism. As a Javanese heritage speaker who was born and raised in Bandung, Harni learnt to speak both Javanese and Sundanese in family and community settings. From her schooling experience, she learned to speak Indonesian and English. She often uses Javanese and Indonesian with family members. When she talks to school friends who are Sundanese, they are likely to speak in Indonesian and Sundanese at the same time, with a few lexical items of English as well. In general, the more languages that interlocutors share in Indonesia, the more languages will be deployed in the exchange, regardless of their

(c) The Author(s). 2018 Open Access This article is distributed under the terms of the Creative Commons Attribution 4.0 International License (http://creativecommons.org/licenses/by/4.0/), which permits unrestricted use, distribution, and reproduction in any medium, provided you give appropriate credit to the original author(s) and the source, provide a link to the Creative Commons license, and indicate if changes were made. 
ethnic background. Such free code-switching or mixing of languages occurs in many multilingual societies where languages are in contact.

In multilingual communities, language mixing is also a common practice in more formal institutional settings such as classrooms. In Indonesian classrooms, teachers and students regularly actualize their multilingual repertoire during teaching and learning. However, despite being the norm in everyday life of multilingual communities, and studies showing its benefits and functions in teaching and learning, code-switching in language learning classrooms remains a hotly debated topic worldwide.

\section{Aim and structure of this paper}

To help inform this debate, this paper offers a model for analysing the structures and functions of language use in multilingual classrooms. Multilingual interactions in classroom discourse are described here as language shift. ${ }^{1}$ Language shift is the process of meaning making realized in two or more languages. This includes 'translating' or bringing equivalence from L1 to L2, as well as 'code-switching/mixing', or using two or more languages in spoken discourse.

The analysis in this paper can be applied to empirically describe precisely how and why language shift is used in pedagogic settings. The aim of the analysis is to develop a set of systematic principles towards design of effective bilingual teaching and learning. The language shift analysis model includes three major components. The first component is a framework for identifying types of L2 language teaching approaches along two axes: the degree to which they favour L2 or L1 as the language of instruction, and their focus on language or curriculum content as the primary learning goal. This is a topological framework on which various approaches can be located and compared (following Bernstein, 2000; Martin \& Rose, 2008; Maton, 2013). The second is a description of the structuring of language shift in teaching/learning interactions. Pedagogic interactions are analysed in terms of the roles of speakers, and the moves they make in exchanges. This analysis deploys the tools of exchange structure theory (Martin, 1992; Martin \& Rose 2007). We show that language shift may occur from role to role, from move to move, and within moves. The third component is an analysis of the pedagogic functions of such language shift in multilingual classrooms. For example, L1 may be used by teachers to scaffold learning tasks, or to engage students in the learning activity. The use of L1 for such functions may give way to L2 as students' L2 knowledge and confidence grows. This analysis uses the tools of pedagogic register analysis (Rose, 2014, 2018a; Rose \& Martin, 2012).

\section{Research method}

The analysis model was developed in the context of an action research project in Indonesian schools (Kartika-Ningsih, 2016). The project was interventionist in nature in that it sought to develop an ideal model of bilingual teaching practices. It used the genre-based literacy methodology known as Reading to Learn (R2L) (Rose, 2018b; Rose \& Martin, 2012, 2014), which was adapted and extended to suit Indonesian multilingual classrooms. The R2L methodology is a system of teaching strategies that guide learners to read and learn from reading, and then 
use what they have learnt from reading in their writing. However, the aim of this paper is not to describe this pedagogic model, but rather the language shift analysis that was developed from the research.

The research project involved classes from two secondary schools, representing common types of multilingual classrooms in Indonesia. One school was more economically advantaged than the other, but both schools shared similar linguistic backgrounds. Most teachers and students in both schools spoke Bahasa Indonesia as well as Sundanese as the regional language. English as a foreign language was a major subject in the school curriculum, and was thus a familiar language for students and teachers in the area.

The students included boys and girls in Year 8 (13-15 years old). At the time of intervention, English and biology were learned within an integrated literacy program. The curriculum goal for English was to write descriptive reports; the goal for biology was to study endangered species. The intervention program was designed for students to write descriptive reports in English about endangered Indonesian birds.

Briefly, the intervention involved jointly reading descriptive reports in detail, making notes on the board from these texts, and writing new texts on the board from the notes. In the R2L methodology, these activities are known as Detailed Reading, Note-making, and Joint Construction (Rose \& Martin, 2012). This sequence was repeated three times with each class. In the first two iterations, an L1 (Indonesian) text was read, notes were made in L1 and translated into L2 (English), and an L2 text was written from the notes. In the third iteration, an L2 text was read, and notes and a new text were written in L2. Students then independently researched, made notes and wrote their own texts in L2. Results included significant improvements in all students' L2 writing (Kartika-Ningsih, 2016).

Data were collected in the form of video and audio recordings of classes during the intervention. The analysis focuses on the teaching learning activities and the interactions between teachers and students.

\section{Mapping the focus of multilingual teaching practices Debate on L1 use in L2 learning}

It has been argued for many years that L2 teaching should take place only in the target language, as using L1 in the classroom is an obstacle for L2 learning (Howatt, 1984; Lambert, 1984; Yu, 2000 in Cummins, 2014). One reason often given is that L1 is a source of interference and hence errors in students' L2 speech and writing production. Another is that an L2 only classroom may be the only environment where students living in a non-L2 community can be immersed in the target language.

Conversely, the L2 only position has been criticised as oriented to monolingualism and native-speakerism, rather than the reality of multilingual environments (Lin, 2013). Studies of code-switching argue for the benefits of L1 use in L2 learning (Canagarajah, 2011; Levine, 2011; Lin, 2015). The term translanguaging has been proposed to distinguish effective code-switching from random practices (Garcia and Wei, 2014). There have been a number of studies describing code-switching practices (Creese \& Blackledge, 2010; Lin, 2015). However, these studies have generally not provided pedagogical frameworks or models which can be applied by teachers in multilingual environments. Identifying effective language shift practices remains a challenge. 
A particular concern for identifying effective practices is the focus on either language or content discrimination in various L2 teaching programs. Language-focused programs often emphasize knowledge about language, privileging particular 'language skills' as building blocks towards L2 competence. Types of language focus commonly found in teaching methods offered for EFL education include grammatical knowledge, L1 to L2 translation, or communication purposes. On the other hand, content-focused approaches may attempt to integrate language with subject discipline knowledge. For example, CLIL programs involve the teaching of subjects such as biology or mathematics in L2 (e.g. Coyle et al., 2010; Cenoz et al., 2014). However there is 'no single pedagogy' for CLIL programs (Coyle et al., 2010, p.86). While they share a common focus on subject content, there is no standardization of implementation, including the use of L1 and L2 in the classroom.

\section{A framework for mapping multilingual teaching focus}

A systematic analysis of the use of L1 and L2 in multilingual classrooms must consider both the extent of L1 and L2 use, and the teaching focus on language or content. For this purpose, we will introduce the terms 'enveloping' for teaching practices favouring L2 use, as learners are 'enveloped' in the target language, and 'enfolding' for practices favouring L1 use, as the target language is 'enfolded' in the use of L1 (Kartika-Ningsih, 2016). These neutral terms are preferred to value-laden metaphors like 'immersion', which invoke quasi-religious inferences such as revelation by baptism, in place of empirical analysis of pedagogic practice.

In Fig. 1, variations in language use and teaching focus in L2 teaching are mapped as a topology, with two axes. One axis is language use in L2 classrooms. At one pole of this axis, L2 only practice is termed 'enveloping'. At the other pole, mixed L1 and L2 use are termed 'enfolding'. The other axis is the teaching focus, on either content or language. At one pole, language is the primary focus of the L2 teaching method. At the other pole, content is the primary focus in subject discipline teaching in L2. This creates four quadrants which allow placement of various teaching approaches, depending on their language use and teaching focus.

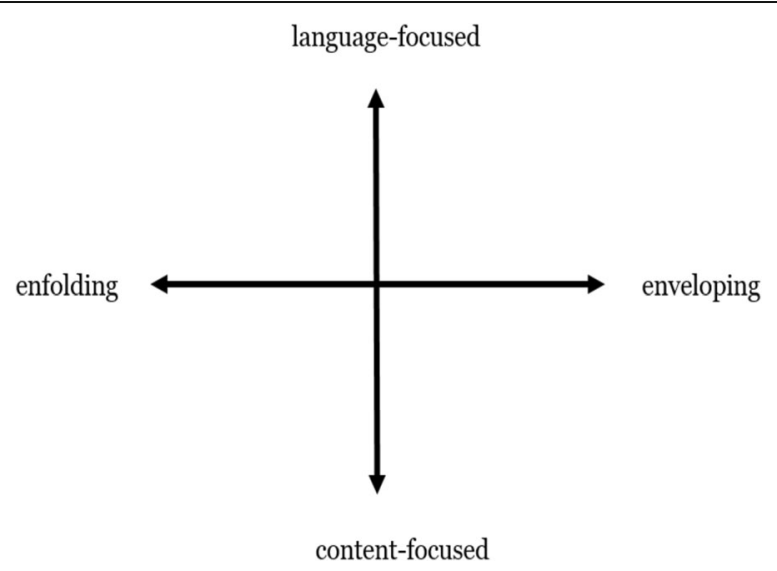

Fig. 1 Topology of bilingual education programs. The topology of bilingual education programs consists of two intersecting axes. The vertical axis reveals language learning on two poles: language-focused at the top end and content-focused at the bottom end. The horizontal axis represents language use which involves enfolding as a cline with L1 as transitional and enveloping at the other one as L2 only use 
The aim of this topology is not to prioritize one teaching method over another, nor to suggest keeping L2 learners in enfolding or enveloping practices. The critical point is to consider how L2 teaching and learning involves L1 and L2 use, and how language and content are taken into account. To this end, it is essential to carefully describe the structures and functions of language shift in pedagogic practices.

The sequence of pedagogic activities in the intervention can be positioned in this framework, as follows. Firstly, the primary curriculum goal was language-focused, for students to write a descriptive report in L2 (English). However, this language focus was embedded in a content-focused curriculum goal, to learn about a scientific field, biological classification and description. These goals were integrated by studying L1 and L2 texts about bird species, and using note-making and joint construction to write L2 texts on this topic. Secondly, the language of instruction varied with the activities. In the early stages of the teaching sequence, enfolding practices predominated, to support students to gain control of the curriculum field enfolded in L1 use. As students' control of the field and language skills developed, reading and writing in L2 became enveloped in L2 use.

\section{Re-examining multilingual classrooms}

Two dimensions of multilingual classrooms need to be considered in analyses. One is multilingualism, where two or more languages may be deployed in interactions. The other is the structuring of teacher/student relations in the institutional setting of the classroom. To this end, the SFL model of text-in-context is drawn on to describe the structuring of teacher/learner interactions, and the functions of language shift in these interactions.

\section{Text-in-context model: Theoretical framework}

The systemic functional (SFL) model of language as text-in-context identifies three broad dimensions of social contexts, including the tenor of social relations between interactants, the field of their activities, and the mode of meaning making, as spoken or written language or other modalities (Halliday, 1978). These are variables in the contextual stratum of register. They are configured together at the level of genre, that is, a genre is a configuration of variations in field, tenor and mode (Martin, 1992; Martin \& Rose, 2007, 2008). Field, tenor and mode are realised by distinct metafunctions in language, including ideational, interpersonal and textual metafunctions. Language is also stratified in three strata, as discourse semantics, lexicogrammar and phonology/graphology. This model of language in context is set out in Fig. 2.

This model is useful to investigate multilingual interactions in classroom settings, because it allows us to choose certain dimensions to focus on that are relevant for the study. Starting at the top, the genre of classroom lessons is known as a curriculum genre (Christie, 2002; Rose \& Martin, 2012). Curriculum genres configure two registers together. One is a pedagogic register that includes pedagogic activities (field), teacher/ learner relations (tenor) and the spoken, written, visual and other modalities they use (mode). Through these pedagogic activities, relations and modalities, teachers and learners exchange knowledge and values which are known as a curriculum register (Rose, 2014, 2018a). 


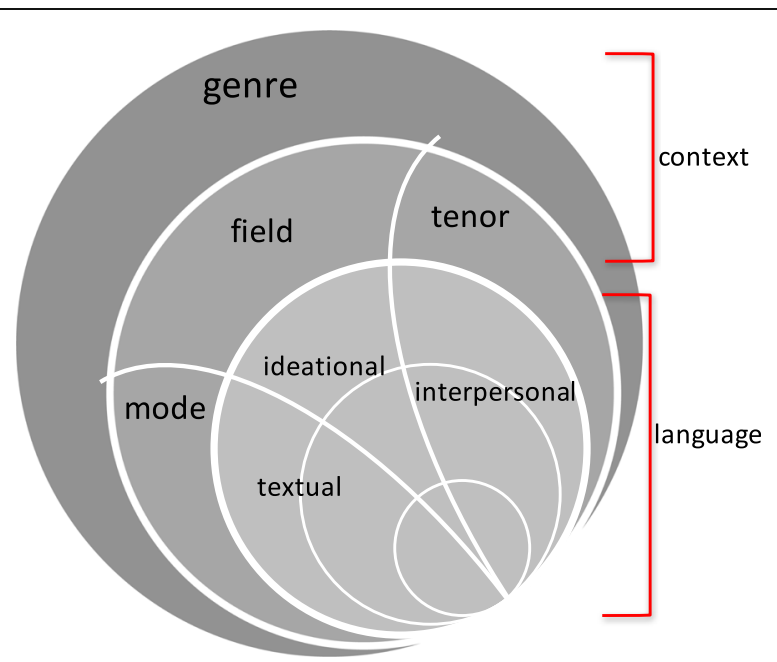

Fig. 2 The SFL model of language in social context. Language model in genre pedagogy adopts language in social contexts, represented as a layered circle. Context consists of genre, mode, field, and tenor. Genre or text type is positioned on top of the co-tangential circles. Mode, field and tenor are within the top of the co-tangential circles. Language consists of textual, ideational and interpersonal metafunctions. Textual metafunction corresponds to mode, ideational to field and tenor to interpersonal

Curriculum genres can be contrasted with knowledge genres, which include the written genres of the school, such as stories, chronicles, explanations, reports, procedures, arguments and text responses (Martin \& Rose, 2008). Knowledge genres configure the fields of curriculum subjects, such as history, science, mathematics, literature. Students learn to read and write these knowledge genres, at the same time as learning the curriculum content, by participating in the curriculum genres of the classroom. While curriculum content is taught explicitly, its knowledge genres are usually left implicit, but can be made explicit (Rose \& Martin, 2012). For example, in the lessons reported here students learnt to read and write scientific reports at the same time as learning about bird species. Understanding that language realises both genre and register enables explicit language teaching to be embedded in subject teaching.

\section{Structures of pedagogic exchanges}

Pedagogic activities and relations are enacted in language by exchanges between teachers and learners. The structures of exchanges, and speakers' roles in them, are options in the discourse semantic system of NEGOTIATION. Speakers take up roles such as giving or demanding goods, services or information, and these roles may initiate an exchange or respond to preceding roles.

An exchange may negotiate either knowledge or action, and speakers may take a primary or secondary role in either. In an action exchange, the role that performs the action is the primary actor (A1), and the role that demands the action is a secondary actor (A2). In a knowledge exchange, the role that that provides the knowledge is the primary knower (K1), and the role that demands the knowledge is a secondary knower (K2). 
If an exchange is initiated by a primary $\mathrm{A} 1$ or $\mathrm{K} 1$ role, it may constitute the whole exchange, simply by performing the action or providing knowledge. For example, teachers commonly present knowledge in single $\mathrm{K} 1$ roles that constitute the whole exchange.

An exchange may be initiated by a secondary A2 or K2 role, which demands action or knowledge and is followed by an A1 or $\mathrm{K} 1$ role, performing the action or providing the knowledge. Table 1 shows an example. In addition, the secondary knower follows up with thanks, labelled $\mathrm{K} 2 \mathrm{f}$.

If an exchange is initiated by a primary actor or knower, it may also anticipate an A2 or $\mathrm{K} 2$ response. In this case the initiating role is a delayed primary role (dA1 or dK1). For example, dA1 May I leave? - A2 Yes you may - A1 [leaves]. In a very common pattern in curriculum genres, the teacher initiates with a question, a learner responds, and the teacher evaluates the response. Although the learner displays knowledge, the teacher is the primary knower with the authority to evaluate the learner's knowledge. An example is Table 2, in which a class is reviewing knowledge about the text type procedure.

This excerpt includes two numbered exchanges, each initiated by the teacher as dK1. In exchange 1, the teacher initiates by leaving the end of her sentence empty (...), which invites learners to supply the missing element. Several students respond by supplying the missing word 'procedure', and the teacher affirms by approving and repeating their response. In exchange 2, the teacher extends with a further question, one student responds and the teacher affirms by repeating the response.

\section{Language shift in classroom interactions}

\section{Types of language use}

In multilingual classrooms, language shift takes part during learner/teachers interactions. There are four general patterns of language use in such classrooms, including:

- L1 only

- L2 only

- L1 and L2

- L1, L2, and L3.

These four language use options are illustrated here in examples from Indonesian classes, in which students are learning English as a foreign language (EFL), in other words as L2. Table 1 was an example of an L2 only interaction, as it is conducted entirely in English in an Indonesian classroom.

Table 3 exemplifies L1 only dialogue in Indonesian. Each move is translated below in italics. The teacher and students are discussing the word 'beaker' and the

Table 1 Knowledge exchange

\begin{tabular}{lll}
\hline A & K2 & What time is it? \\
B & K1 & - half past six \\
A & K2 $f$ & - thanks. \\
\hline
\end{tabular}


Table 2 Exchanges in a classroom interaction

\begin{tabular}{llll}
\hline 1 & T & dK1 & OK, I will try to remind you about... \\
& SS & K2 & Procedure! \\
& T & K1 & Yeah! Procedure text. \\
T & dK1 & What is the function of procedure text? \\
S1 & K2 & To tell. \\
& T & K1 & To tell. \\
\hline
\end{tabular}

reason it is named beaker. The Indonesian word for beaker is borrowed from English, along with the English spelling. The teacher initiates by leaving the end of her sentence empty, and two students attempt to supply the missing word. However, this is not the answer the teacher wants, and she provides the word herself (claiming it is called 'beaker' because its spout resembles a bird's beak or paruh in Indonesian.)

Table 4 exemplifies both L1 and L2 used in the same dialogue. This time the teacher and the students are talking about conjunctions that are used in procedure texts. English wordings are included in the Indonesian discussion. The teacher initiates in Indonesian, in which the word class 'temporal conjunction' and example 'first' are in English. A student responds with another English example 'then', and the teacher affirms in Indonesian. English words are underlined.

Table 5 exemplifies language interplay where three languages are involved, Indonesian, English and Sundanese. The teacher initiates by asking the English name for Indonesian pinset 'tweezers'. One student guesses the English word 'princess' from the sounds, another proposes the Sundanese word cocolok 'skewer', and the Sundanese word panyapit 'tongs'. The teacher ignores all these incorrect answers and writes the English word 'tweezers' on the board. (The Indonesian word pinset is actually borrowed from Dutch for 'tweezers'.)

These four examples of different patterns of language use portray typical interactions in multilingual classrooms. In Indonesian classrooms, L1 is used pervasively as it is part of the students' everyday life, despite teachers' efforts to use more L2. Teachers often use L2 for the goals of language knowledge, but use L1 to manage classrooms.

Table 3 L1 only interaction

\begin{tabular}{lll}
\hline $\mathrm{T}$ & $\mathrm{dK} 1$ & Ada juga yang bilang beaker, karena gelasnya itu ada... \\
& $\mathrm{K} 2$ & Some say it is beaker, because this glass has... \\
$\mathrm{S} 1$ & Ukur & Measure \\
& $\mathrm{K} 2$ & Ukurannya \\
$\mathrm{S} 2$ & $\mathrm{~K} 1$ & Its measurement \\
& & Paruhnya \\
$\mathrm{T}$ & Its beak \\
\hline
\end{tabular}


Table $4 \mathrm{~L} 1$ and $L 2$ use

\begin{tabular}{lll}
\hline $\mathrm{T}$ & $\mathrm{dK} 1$ & $\begin{array}{l}\text { Yang temporal conjunction itu kan yang kayak first. } \\
\text { Temporal conjunction is, for example, 'first'. }\end{array}$ \\
$\mathrm{S} 1$ & $\mathrm{~K} 2$ & $\frac{\text { Then }}{\text { T }}$ \\
$\mathrm{T} 1$ & Kayak gitu. \\
& (Yes) like that. \\
\hline
\end{tabular}

\section{Structures of language shift in exchanges}

Tables 4 and 5 illustrated language shift, occuring between roles in an exchange, from $\mathrm{dK} 1$ to $\mathrm{K} 2$ and $\mathrm{K} 1$ roles. Language shift can also occur within roles, between and within moves.

Each role in an exchange includes one or more moves, that are realized in grammar by a major or minor clause (Martin, 1992; Martin \& Rose, 2007). Hence the structures of exchanges consist of three ranks: the whole exchange, the roles of speakers, and the moves they make in the exchange. A role consists of one or more moves, an exchange consists of one or more roles, and there may be a series of exchanges in an interaction.

In the structures of exchanges, three types of language shift are possible: between roles, or 'interrole'; between moves within roles, or 'intermove'; and within moves, or 'intramove'. These three types are described as follows.

In interrole language shift, a teacher may use one language in the initiating roles of an exchange and another language in the closing roles, while students may use either language. Table 6 illustrates interrole language shift between teacher and students. In the first two roles, labeled as $\mathrm{K} 1$ and $\mathrm{dK} 1$, the teacher uses L1 (Bahasa Indonesia) to ask for the Latin name of a bird. A student responds with the Latin name, and the teacher affirms in L2 (English).

Intermove language shift occurs when a teacher uses both L1 and L2 in the initiating and/or closing roles of an exchange. In Table 7, two examples of intermove shift are shown. In the first role (A1) the teacher directs students' attention to the text in L2. In the following $\mathrm{K} 1$ roles, she refers to the sentence in L1 in one move, then reads in L2 in the next move. (Note that, while reading, she also glosses the L2 words 'soft' and 'tail' as L1 words). In the following $\mathrm{dK} 1$ role, the teacher uses L2. A student then responds in L1 in one move, but then identifies the wording in L2. The teacher then affirms in L2 in two moves.

Intramove language shift is perhaps the most common type of language shift found in both daily life and multilingual classroom settings. In Table 8, the teacher and

Table $5 \mathrm{~L} 1, \mathrm{~L} 2$ and $\mathrm{L} 3$ use

\begin{tabular}{lll}
\hline $\mathrm{T}$ & $\mathrm{dK} 1$ & What is pinset? \\
$\mathrm{S} 1$ & $\mathrm{~K} 2$ & $\frac{\text { Princess? }}{\text { Cocolok! }}$ \\
$\mathrm{S} 2$ & $\mathrm{~K} 2$ & Skewer! \\
$\mathrm{S} 2$ & $\mathrm{~K} 2$ & Ada juga panyapit bu. \\
$\mathrm{T}$ & $\mathrm{K} 1$ & There's also 'tongs', ma'am. \\
\hline
\end{tabular}


Table 6 Inter-role language shift

\begin{tabular}{lll}
\hline T & Ini ada satu nama yang disebutnya nama Latin. & $\mathrm{K} 1$ \\
& There is this one name which is mentioned as the Latin name & dK1 \\
& Apa nama Latinnya? & \\
& What's the Latin name? & $\mathrm{K} 2$ \\
Ss & Nisaetus bartelsi. & $\mathrm{K} 1$ \\
$\mathrm{~T}$ & OK, good. & $\mathrm{K} 1$ \\
& Nisaetus bartelsi. &
\end{tabular}

students are jointly constructing a new sentence from notes written in L2. In the first K1 move, the teacher uses L1 to refer to the sentence on the board, but then reads it in L2. In the next K1 move, she uses L1 to refer to the next sentence to be written, but names its topic in L2. In the following dK1 move she asks a question in L1, but with an L2 topic, and clarifies in L2 but reads from the notes in L2. A student then responds in L2 and the teacher affirms in L2.

Figure 3 displays the options for language shift in exchanges as a system network. The first choice is between interrole and intrarole (between or within exchange roles). Intrarole then has a further option of intermove and intramove (between or within exchange moves).

The language shift system provides an explicit framework for analysing code-switching in multilingual classroom interactions. It addresses common patterns of language interplay such as translating, or bringing equivalence from L1 to L2 or vice versa, as well as 'code-switching' or using two or more languages in the interactions. This analysis offers the possibility of measuring effectiveness of multilingual teaching and learning.

\section{Pedagogic functions of language shift}

As language functions in social contexts, identifying the pedagogic functions of language shift involves a step up from the discourse structures of exchanges to the contextual stratum of register. In terms of pedagogic register, language shift may function to scaffold the teaching/learning activity, to enact teacher/learner relations, or to

Table 7 Intermove language shift

\begin{tabular}{ll}
\hline $\mathrm{T}$ & Now I want you to focus on the first sentence. \\
$\mathrm{T}$ & Yang ini ya \\
This one. \\
(reading) Gould described this bird in 1858, naming it the Crowned Wren. Malurus is from the \\
Greek for 'soft' (malocos) and 'tail' (oura), which refers to the soft tail feathers; coronatus is \\
Latin for 'crowned', a reference to the male's purple crown. \\
I want you to find the genus of this species. \\
Aku tahu! \\
I know! \\
$\quad$ Malurus! \\
$\quad$ OK, good! \\
Very good!
\end{tabular}


Table 8 Intramove language shift

\begin{tabular}{|c|c|c|}
\hline \multirow[t]{2}{*}{ T } & Ini kalimatnya sudah mulai 'The female is like the non-breeding male' & $\mathrm{K} 1$ \\
\hline & This sentence has started with $<<$ The female is like the non-breeding male $>>$ & \\
\hline \multirow[t]{2}{*}{ T } & Kalimat selanjutnya akan menerangkan the female. & \\
\hline & The next sentence will explain $<<$ the female $>>$. & \\
\hline \multirow[t]{2}{*}{ T } & Apa deskripsi yang dimiliki the female, yaitu large chestnut ear coverts? & $\mathrm{dK} 1$ \\
\hline & What description does $<<$ the female $>>$ have, that is $<<$ large chestnut ear coverts $>>$ ? & \\
\hline Ss & The female has large chestnut ear coverts. & K2 \\
\hline $\mathrm{T}$ & Good, very good! & $\mathrm{K} 1$ \\
\hline
\end{tabular}

present the sources of meanings. In order to show the functions of language shifts, this section introduces analyses of these three dimensions of pedagogic register. Values in pedagogic register that are applied in the analyses here are set out as tables in the Appendix to this chapter.

\section{Structures of pedagogic activity}

Pedagogic activities are structured in hierarchies of lesson stages composed of one or more lesson activities, that are composed of one or more learning cycles at the level of teacher/learner exchanges. Activities at each of these three ranks are centred on a learning task, through which knowledge is construed by learners; macro-tasks at the level of lesson stages, and micro-tasks at the level of learning cycles. Learning tasks are typically focused (specified) and then evaluated by a teacher. In addition, teachers may first prepare learners to succeed with the task, and the knowledge they construe through the task may then be elaborated. These five structural elements are termed Prepare, Focus, Task, Evaluate and Elaborate phases (Martin \& Rose, 2007; Rose \& Martin 2012). The orbital structuring of pedagogic activities as nuclear and marginal phases is diagrammed in Fig. 4.

At the rank of learning cycles, each of these phases may be enacted by a single exchange role. At this level, a common task of learners is to respond to teachers. This task is typically focused with a question or command, and then evaluated by affirming or rejecting. The Focus is typically a dK1 role, the Task is K2 and Evaluate is $\mathrm{K} 1$. Prepare and elaborate phases are additional exchanges that may be single K1 roles. The mapping of these elements on exchange structures is exemplified in Fig. 5. This is an exchange series, as the Prepare and Elaborate phases are additional exchanges consisting of a single K1 role. Double slashes indicate boundaries between exchanges in series.

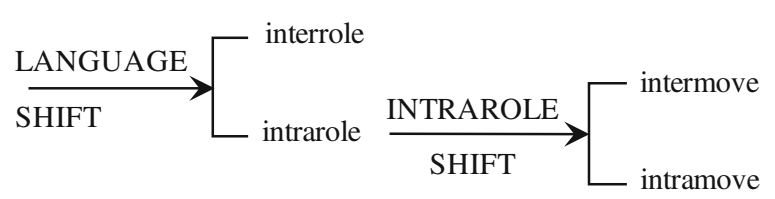

Fig. 3 Options for language shift in exchanges. Language shift system consists of two options: interrrole and intrarole. Intrarole has a further option: intermove and intramove 


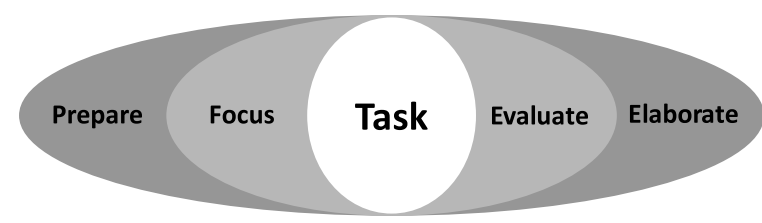

Fig. 4 Nuclear and marginal phases of learning cycles. Learning cycles are orbital with nuclear and marginal phases. The nuclear phase consists of Focus - Task - Evaluate, Task being the core phase of the cycles. The marginal cycles are Prepare and Elaborate

Table 9 illustrates the phases of a learning cycle, along with the matter that each phase is concerned with. The class is reading an L1 (Indonesian) factual text in detail, identifying and discussing wordings in each sentence. In this learning cycle, the students' task is to identify a wording in the sentence, the Latin name for a bird species, Nisaetus bartelsi. The teacher prepares this task in two K1 moves, using L1. First, she gives the wording she is after, within the statement it's about names of Nisaetus bartelsi. Then she gives a further clue, one name which is mentioned as the Latin name. The $\mathrm{dK} 1$ Focus then asks students to identify this, What's the Latin name, again in L1. Students identify the wording in the sentence, and the teacher affirms in L2, OK, good, and repeats the answer. A dotted line marks exchanges within this learning cycle.

In this cycle, the functions of L1 use are apparently to prepare and focus the task of identifying wordings in an L1 text. Language shift occurs in the evaluating phase. As evaluation is a feature of pedagogic relations, this analysis is added in Table 10.

\section{Pedagogic relations: Acts and interacts}

Pedagogic relations include the roles of teachers and learners, termed interacts, and the pedagogic acts that they negotiate. For teachers, these roles include presenting knowledge, evaluating learners and directing the activity. Learners may display knowledge and both learners and teachers may solicit acts from each other. Acts include pedagogic behaviours and acts of consciousness, illustrated in Table 11. Realisations of acts and interacts are underlined in transcripts, where possible.

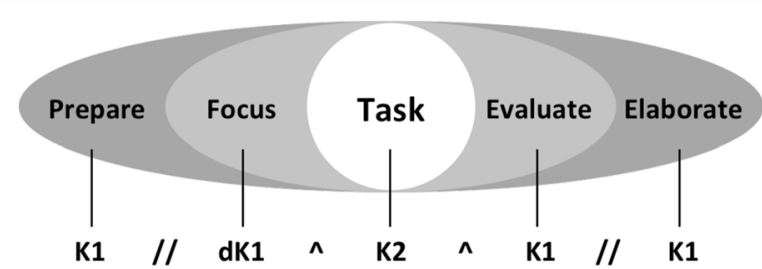

Fig. 5 Phases of pedagogic activities enacted by exchange roles. The orbital structures of learning exchange correspond to exchange roles in pedagogic activities. At the nuclear cycles, Focus is realized as $\mathrm{dK} 1$, Task as K2 and Evaluate as K1. In marginal cycles, Prepare is realized as K1 and Elaborate as K1 
Table 9 Phases in a learning cycle

\begin{tabular}{ll}
\hline T Nah sekarang kita mengenai nama-nama Nisaetus bartelsi karena dia punya & phase matter \\
banyak nama. & K1 Prepare wording \\
So now it's about names of Nisaetus bartelsi, because it has a lot of names. & $\mathrm{K} 1$ \\
Ini ada satu nama yang disebutnya nama Latin. & dK1 Focus wording \\
There's this one name which is mentioned as the Latin name. & K2 Identify wording \\
Apa nama Latinnya? & $\mathrm{K} 1$ Affirm \\
What's the Latin name? & \\
Ss Nisaetus bartelsi. & \\
T OK, good. & \\
Nisaetus bartelsi. & \\
\hline
\end{tabular}

Table 10 re-analyses the same interaction as Table 9, in terms of acts and interacts. By starting the first Prepare move with the L1 words So now it's about, the teacher invites students' anticipation of what will follow in the text [invite anticipation]. The second L1 move then invites their perception of the text There's this one name [invite perception]. The L1 Focus question then directs students to display what they perceive [direct display], and students display their perception by saying the wording, Nisaetus bartelsi [display perception]. ${ }^{2}$ The function of the language shift to L2 is to affirm the students' display [approve display]. While L1 was used in the Prepare and Focus phases to facilitate the acts of anticipating, perceiving and identifying wordings in the L1 text, L2 is used here to amplify the value of affirmation for the students, in the context of a lesson whose goal is L2 learning.

\section{Pedagogic modalities: Sources and sourcing}

Inviting anticipation and perception are interpersonal aspects of guiding learning. As the task is to identify wordings in a text, another aspect is to guide learners towards the wordings, by locating them in the text and describing them. These are features of pedagogic modalities. Pedagogic modalities are the sources of meanings in the learning discourse, and the means of sourcing them into the discourse. Sources of meanings include the environment, spoken knowledge of teachers and learners, and records such

Table 10 Conscious acts

\begin{tabular}{llll}
\hline perceptive & non-specific & & attention \\
specific & visual & perception \\
cognitive & aural & reception \\
& known & & knowledge \\
& & alternative & choice \\
& & implicative & reasoning \\
affective & interpretive & conception \\
& appraising & & disposition \\
& interested & realis & engagement \\
& & irrealis & anticipation \\
\hline
\end{tabular}


Table 11 Acts and interacts

\begin{tabular}{|c|c|c|c|c|c|}
\hline & & & phase & interact & act \\
\hline \multirow[t]{6}{*}{$\mathrm{T}$} & $\frac{\text { Nah sekarang kita mengenai nama-nama Nisaetus bartelsi karena dia }}{\text { punya banyak nama. }}$ & K1 & Prepare & invite & anticipation \\
\hline & $\begin{array}{l}\text { So now it's about names of Nisaetus bartelsi, because it has a lot of } \\
\text { names. }\end{array}$ & & & & \\
\hline & Ini ada satu nama yang disebutnya nama Latin. & K1 & & invite & perception \\
\hline & There's this one name which is mentioned as the Latin name. & & & & \\
\hline & Apa nama Latinnya? & $\mathrm{dK} 1$ & Focus & direct & display \\
\hline & What's the Latin name? & & & & \\
\hline Ss & Nisaetus bartelsi & K2 & Identify & display & perception \\
\hline T & OK, good & K1 & Affirm & approve & display \\
\hline & Nisaetus bartelsi. & & & repeat & \\
\hline
\end{tabular}

as written texts, graphic images and video recordings. Each of these source types has a set of options for sourcing them into the discourse. Options for sourcing from recorded texts are illustrated in Table 12.

In Table 13 the source of meanings is the text that the class is reading in detail. The first Prepare move locates the meanings in the text with the pronoun now it's about, which refers to the text. The second Prepare move describes the meanings, as the Latin name. The Focus question repeats this What's the Latin name, and students identify the wording by reading the text.

Sourcing and interacts work together to prepare and focus the task for students. The first Prepare move invites anticipation at the same time as locating the target meaning in the text. The second move both invites perception and describes the meaning. The Focus facilitates the students' display by repeating the preceding move. These cycle phases are presented in L1 to reduce the students' semiotic labour, when reading an $\mathrm{L} 1$ text.

\section{Functions of language shift in a multilingual literacy lesson}

The detailed reading interaction in Table 9 is an excerpt from the early stages of a lesson sequence, which is ultimately aimed at learning to read and write L2 texts. In a later stage of this lesson sequence, the class is guided to write an L2 text from notes on

Table 12 Options for sourcing meanings from texts

\begin{tabular}{llll}
\hline restate & repeat & read & \\
& recite & \\
& diverge & summarise & \\
& rephrase & \\
indicate & recast & gestural \\
& & verbal & point \\
& pointing & locate & imitate \\
& describing & compare & symbolize \\
& class/part & &
\end{tabular}


Table 13 Sources and sourcing

\begin{tabular}{|c|c|c|c|c|c|}
\hline & & & phase & sourcing & source \\
\hline \multirow[t]{6}{*}{$T$} & $\begin{array}{l}\text { Nah sekarang kita mengenai nama-nama Nisaetus bartelsi karena dia } \\
\text { punya banyak nama. }\end{array}$ & K1 & Prepare & locate & text \\
\hline & So now it's about names of Nisaetus bartelsi, because it has a lot of names. & & & & \\
\hline & Ini ada satu nama yang disebutnya nama Latin. & K1 & & describe & text \\
\hline & There is this one name which is mentioned as the Latin name. & & & & \\
\hline & Apa nama Latinnya? & $\mathrm{dK} 1$ & Focus & repeat & move \\
\hline & What's the Latin name? & & & & \\
\hline Ss & Nisaetus bartelsi & K2 & Identify & read & text \\
\hline $\mathrm{T}$ & Ok, good & $\mathrm{K} 1$ & Affirm & & \\
\hline & Nisaetus bartelsi. & & & & \\
\hline
\end{tabular}

the board that are also written in L2. At this stage, L1 is used more sparingly. Tables 14 and 15 are a longer excerpt from this later lesson stage, comprising a lesson activity. This excerpt illustrates functions of each type of language shift: interrole, intermove and intramove.

The function of this lesson activity is to write a sentence in L2 (English), that describes the female of a bird species, using notes written on the class board in L2. The teacher's goals are to expose students to multiple options for structuring the L2 sentence, to make it coherent in the contexts of the text and the topic. This is achieved by reading the notes, asking students for ideas, and rephrasing them in various wordings. The students' tasks are to perceive the notes and text on the board, to propose ideas for the new sentence, and to follow the teacher's proposals for structuring it.

This activity consists of a task and elaborate phase, comprising three learning cycles each. In the task phase (Table 14), the teacher invites students to reason about an L2 sentence using the notes. In the elaborate phase (Table 15), she models how to reason about the sentence structure, and finally directs one student to scribe the sentence on the board. In the transcript, L1 is marked in bold to make language shifts clear, and types of language shift are labelled in the matter column.

\section{Task phase}

In cycle 1 of the task phase (Table 14), the teacher first directs students' attention in L1, Listen to this. She then prepares the task in two moves involving intramove language shift. She first uses L1 to invite perception of the preceding sentence The sentence has started with, and reads it in L2. She then uses a mix of L1 and L2 to direct the writing activity The next sentence will explain the female. She focuses the task in L1 and L2 by asking students to perceive the note describing the female bird. Student 1 then proposes a whole L2 sentence, which displays her reasoning about an appropriate L2 sentence structure. The teacher praises her in L2 and repeats the sentence to the class, still using an L1 word, S1 bilang 'S1 said'.

In cycle 2, the teacher solicits ideas from other students. She uses intermove language shift to focus the task, first in L2, Any other sentences? and repeats the question in L1. 
Table 14 Language shift in task phase

\begin{tabular}{|c|c|c|c|c|c|c|c|}
\hline & & & & phase & matter & interact & act \\
\hline \multirow[t]{12}{*}{1} & \multirow[t]{6}{*}{$\mathrm{T}$} & Dengarkan ini & A2 & Prepare & sentence & direct & attention \\
\hline & & Listen to this. & & & & & \\
\hline & & $\begin{array}{l}\text { Kalimatnya sudah mulai 'the female is like the non- } \\
\text { breeding male'. }\end{array}$ & K1 & & intramove & invite & perception \\
\hline & & $\begin{array}{l}\text { The sentence has started with 'the female is like the non- } \\
\text { breeding male'. }\end{array}$ & & & & & \\
\hline & & $\begin{array}{l}\text { Kalimat selanjutnya akan menerangkan mengenai the } \\
\text { female. }\end{array}$ & $\mathrm{K} 1$ & & intramove & direct & activity \\
\hline & & The next sentence will explain the female. & & & & & \\
\hline & \multirow[t]{2}{*}{$\mathrm{T}$} & Apa deskripsi yang dimiliki female yaitu? & $\mathrm{dK} 1$ & Focus & wording & inquire & perception \\
\hline & & What description does the female have? & & & intramove & & \\
\hline & S1 & The female has large chestnut ear coverts & K2 & Propose & $\begin{array}{l}\mathrm{L} 2 \\
\text { sentence }\end{array}$ & display & perception \\
\hline & \multirow[t]{3}{*}{$\mathrm{T}$} & Good, very good. & K1 & Affirm & & praise & \\
\hline & & $\begin{array}{l}\text { S1 bilang, which is very good, "the female has large } \\
\text { chestnut ear coverts". }\end{array}$ & $\mathrm{K} 1$ & & intramove & repeat & \\
\hline & & $\begin{array}{l}\text { S1 said, which is very good, "the female has large } \\
\text { chestnut ear coverts". }\end{array}$ & & & & & \\
\hline \multirow[t]{5}{*}{2} & & Any other sentences? & $\mathrm{dK} 1$ & Focus & $\begin{array}{l}\mathrm{L} 2 \\
\text { wording }\end{array}$ & inquire & reasoning \\
\hline & & Ada saran lain? & $\mathrm{dK} 1$ & & intermove & & \\
\hline & & Any other suggestion? & & & & & \\
\hline & S1 & The chestnut ear coverts belong to the female. & K2 & Propose & $\begin{array}{l}\mathrm{L} 2 \\
\text { sentence }\end{array}$ & display & reasoning \\
\hline & $\mathrm{T}$ & Good, very good! & K1 & Affirm & & praise & \\
\hline \multirow[t]{6}{*}{3} & $\mathrm{~T}$ & Any other way? & $\mathrm{dK} 1$ & Focus & $\begin{array}{l}\text { L2 } \\
\text { wording }\end{array}$ & inquire & reasoning \\
\hline & $\mathrm{S} 2$ & The chestnut of ear coverts, emm... & K2 & Propose & $\begin{array}{l}\text { L2 } \\
\text { wording }\end{array}$ & display & reasoning \\
\hline & $\mathrm{T}$ & The female's ear coverts, S2? & K1 & Reject & & qualify & \\
\hline & $\mathrm{S} 2$ & $\begin{array}{l}\text { Ah, the female's ear coverts! Ehm, the female's ear } \\
\text { coverts are... }\end{array}$ & $\mathrm{K} 2$ & Propose & $\begin{array}{l}\text { L2 } \\
\text { wording }\end{array}$ & display & reasoning \\
\hline & Ss & Large chestnut brown! & K2 & Propose & $\begin{array}{l}\text { L2 } \\
\text { wording }\end{array}$ & display & reasoning \\
\hline & $\mathrm{T}$ & Beautiful! & $\mathrm{K} 1$ & Affirm & & praise & \\
\hline
\end{tabular}

Student 2 proposes an L2 sentence, and the teacher praises in L2. Cycle 3 is then entirely in L2. The teacher again asks for other possible sentence structures, Student 3 proposes an incoherent L2 wording, which the teacher rephrases in L2. In terms of evaluation, this rejects S3's proposal, but it also prepares the task, so that S3 repeats it as an L2 sentence beginning. S3 pauses and other students propose a further wording to complete the sentence, which the teacher praises in L2.

\section{Elaboration phase}

In cycle 4 (Table 15), the teacher elaborates on the students' sentence structure proposals in three steps, using intermove and intramove language shift. First, she models a choice between two L2 sentence structures. She invites the choice, using L1 only. She 
Table 15 Language shift in learning cycles continued

\begin{tabular}{|c|c|c|c|c|c|c|c|}
\hline & & & & phase & matter & interact & act \\
\hline \multirow[t]{18}{*}{4} & \multirow[t]{4}{*}{$\mathrm{T}$} & Ada dua, yah? & \multirow[t]{4}{*}{$\mathrm{K} 1$} & Elaborate & \multirow[t]{2}{*}{ L2 sentence } & \multirow[t]{2}{*}{ invite } & \multirow[t]{2}{*}{ choice } \\
\hline & & There are two (options), right? & & & & & \\
\hline & & $\begin{array}{l}\text { Ada "the female has large chestnut ear coverts" atau } \\
\text { "the female's ear coverts are large chestnut". }\end{array}$ & & & intramove & model & choice \\
\hline & & $\begin{array}{l}\text { There's "the female has large chestnut ear coverts" or } \\
\text { "the female's ear coverts are large chestnut". }\end{array}$ & & & & & \\
\hline & \multirow[t]{4}{*}{$\mathrm{T}$} & Nah kita lihat lagi. & \multirow[t]{2}{*}{$\mathrm{dK} 1$} & & & \multirow[t]{4}{*}{ invite } & \multirow[t]{4}{*}{ perception } \\
\hline & & Now let's check again. & & & & & \\
\hline & & $\begin{array}{l}\text { Tadi dibilangnya "the female is like non-breeding } \\
\text { male". }\end{array}$ & \multirow[t]{2}{*}{ K1 } & & \multirow[t]{2}{*}{ intermove } & & \\
\hline & & $\begin{array}{l}\text { It was mentioned "the female is like non-breeding } \\
\text { male". }\end{array}$ & & & & & \\
\hline & \multirow[t]{7}{*}{$\mathrm{T}$} & $\begin{array}{l}\text { Kita mau lanjutkan dengan "the female's ear coverts } \\
\text { are large chestnut". }\end{array}$ & \multirow[t]{10}{*}{ K1 } & & \multirow[t]{3}{*}{ intramove } & \multirow[t]{3}{*}{ model } & \multirow[t]{3}{*}{ reasoning } \\
\hline & & $\begin{array}{l}\text { We want to continue with "the female's ear coverts are } \\
\text { large chestnut". }\end{array}$ & & & & & \\
\hline & & [pointing] & & & & & \\
\hline & & $\begin{array}{l}\text { Tapi berarti selanjutnya tidak bisa disambungkan } \\
\text { dengan ini, "the non-breeding male". }\end{array}$ & & & \multirow[t]{2}{*}{ intramove } & \multirow[t]{4}{*}{ model } & \multirow[t]{4}{*}{ reasoning } \\
\hline & & $\begin{array}{l}\text { But then next we can't connect that with this, "the } \\
\text { non-breeding male." }\end{array}$ & & & & & \\
\hline & & Karena ear covertsnya berbeda. & & & \multirow[t]{2}{*}{ intramove } & & \\
\hline & & (It's) because their ear coverts are different. & & & & & \\
\hline & & Jadi kita pakai 'has' saja ya. & & & \multirow[t]{3}{*}{ intramove } & model & reasoning \\
\hline & & So let's just use 'has'. & & & & & \\
\hline & & The female has large chestnut ear coverts. & & & & model & knowledge \\
\hline \multirow[t]{4}{*}{5} & $S$ & $\begin{array}{l}\text { [scribes sentence up to 'chestnut' incorrectly spells } \\
\text { 'chesnut'] }\end{array}$ & K2 & Propose & spelling & display & knowledge \\
\hline & \multirow[t]{2}{*}{ T } & Chestnut. & \multirow[t]{3}{*}{ K1 } & \multirow[t]{3}{*}{ Reject } & \multirow[t]{3}{*}{ spelling } & qualify & \\
\hline & & [pointing] & & & & direct & attention \\
\hline & $\mathrm{S}$ & [corrects spelling, finishes sentence] & & & & display & knowledge \\
\hline \multirow[t]{5}{*}{6} & $\mathrm{~T}$ & Akhir kalimat pakai apa? & \multirow[t]{2}{*}{$\mathrm{dK} 1$} & \multirow[t]{2}{*}{ Focus } & punctuation & \multirow{2}{*}{ inquire } & knowledge \\
\hline & & The end of the sentence what do you use? & & & interrole & & \\
\hline & $\mathrm{S}$ & [puts a period] & K2 & Propose & punctuation & display & knowledge \\
\hline & $\mathrm{T}$ & A period! & K1 & Affirm & & repeat & display \\
\hline & $\mathrm{T}$ & Excellent! & & & & praise & \\
\hline
\end{tabular}

then states the L2 options, but frames the choice in L1 words, ada 'there's' and atau 'or' (intramove shift). In the second step, she uses L1 to invite perception of the preceding sentence, then reads it in L2, but frames it in L1, tadi dibilangnya 'it was mentioned' (intramove). In the third step, she models reasoning about the appropriate L2 structure to follow this sentence, and uses L1 to frame each step in the reasoning (intramove). Finally she states the L2 sentence.

In cycles 5-6 a student scribes the sentence with the teacher's guidance. In 5, this task is labelled as propose spelling, as the student makes a spelling error which the teacher rejects by saying the correct L2 pronunciation and pointing at the word in the 
notes, which prepares the student to correct the spelling. In 6, the teacher focuses on punctuation with an L1 question, reminding the student to write a period, which the teacher affirms by naming it and praising her.

In sum, there are two phases in this activity. In both phases, there is an overall trend from more L1 when preparing and focusing to more L2 as tasks are evaluated and elaborated. Technically speaking, preparing and focusing tend to be enfolded in L1, while evaluating and elaborating tend towards enveloping in L2.

Within each learning cycle, the teacher tends to use L1 in the first moves for directing attention, directing the activity, and asking students to reason, perceive or remember. As the activity is concerned with L2 text, the following moves tend to mix L1 and L2. L1 is used for framing the tasks, for example, for modelling reasoning about L2 sentence structures. On the other hand, the students' tasks are to propose L2 wordings, and the teacher consistently affirms them in L2. Thus the overall trend in each phase is from L1 only in teacher's initial moves, to intramove language shift within following moves, to L2 only in students' tasks and teacher's affirmation.

\section{Conclusion}

This paper has offered a brief illustration of language shift analysis in multilingual pedagogic practice. Language shift was defined as the process of meaning making realized in two or more languages, incorporating popular concepts such as 'code-switching' and 'translanguaging'.

The analysis included three components. The first was a topology of multilingual teaching approaches, to map the curriculum focus on language or content, and the pedagogic use of L1 or L2, using the terms 'enfolding' in L1 and 'enveloping' in L2. The second was an exchange structure analysis of pedagogic interactions, to show the structures of language shift beween speaker roles (interrole), between moves within each role (intermove), and within moves (intramove). The third was an analysis of the pedagogic functions of language shift, at the contextual level of register. It was found that language shift varied with phases in learning cycles, and with sequences of learning cycles and lesson stages. L2 learning tended to be enfolded in L1 use at the start of sequences, and increasingly enveloped in L2 use towards the end of sequences. Within learning cycles, teachers tended to use language shift of each type in preparing L2 learning tasks, and in elaborating meanings, while students tended to respond in L2, and teachers evaluated responses in L2.

We should emphasise that this is a preliminary study, designed to develop the language shift analysis tools and test their application. In this case, the tools were developed and applied to analysing patterns of language shift in a designed intervention in an action research project. This intervention was deliberately designed as a scaffolded language development sequence, from reading and writing in L1 to reading and writing in L2. Furthermore, within the first two iterations of this teaching sequence, reading texts and writing notes in L1 provided a foundation for writing notes and texts in L2. Hence, L2 development was deliberately enfolded in L1 use in early stages, and enveloped in L2 use in later stages. The language shift analysis tools developed in this 
context need to be tested, refined and extended in a variety of other multilingual classroom settings.

In our view, the aim of further developing and applying the language shift analysis is to identify and design language teaching practices that are effective for all learners. A benefit of this approach is that decisions about language use in multilingual classrooms can be based on empirical evidence of efficacy, rather than ideological commitments to one practice or another. The action research project here used language shift carefully to scaffold students' L2 language development, with significant results. These improvements were achieved, not by favouring L1 or L2 use, or focusing on either language or content. Rather it embedded language development in curriculum content, and enfolded in L1 or enveloped in L2 where appropriate. The trend at each rank of lesson stage, lesson activity and learning cycle is from enfolding in L1, to intramove language shift, to enveloping in L2 as students' skills and confidence grows. As multilingualism grows across the globe, we hope that the tools developed here will help researchers design increasingly effective and inclusive language pedagogy practices.

\section{Endnotes}

${ }^{1}$ The term language shift here is to refer to the system of code-switching, not to be confused with the same term used in sociolinguistics.

${ }^{2}$ The term [display] is used, as learners display for teacher evaluation.

\section{Appendix}

Pedagogic Register Analysis

Tables 16-20 set out the values in pedagogic activities, modalities and relations that are applied in analyses above. See Rose (2018a) for further discussion.

Table 16 Learning cycle phases

\begin{tabular}{|c|c|c|c|c|c|}
\hline \multirow[t]{9}{*}{ Nuclear Phase } & \multirow[t]{2}{*}{ focus } & guided & \multicolumn{3}{|c|}{ explicit criteria } \\
\hline & & unguided & \multicolumn{3}{|c|}{ criteria implicit } \\
\hline & \multirow[t]{5}{*}{ task } & manual & \multicolumn{3}{|l|}{$\ldots$} \\
\hline & & semiotic & \multirow[t]{2}{*}{ displaying } & identify & in text \\
\hline & & & & propose & from knowledge \\
\hline & & & \multirow[t]{2}{*}{ receptive } & receive & verbally \\
\hline & & & & perceive & visually \\
\hline & \multirow[t]{2}{*}{ evaluate } & \multicolumn{4}{|l|}{ affirm } \\
\hline & & \multicolumn{4}{|c|}{ reject (if not affirmed) } \\
\hline \multirow[t]{3}{*}{ Marginal Phase } & prepare & \multicolumn{4}{|c|}{ with explicit criteria before focus } \\
\hline & elaborate & monologic & \multicolumn{3}{|c|}{ teacher knowledge } \\
\hline & & dialogic & \multicolumn{3}{|c|}{ negotiated with learners } \\
\hline
\end{tabular}


Table 17 Record sources

\begin{tabular}{|c|c|c|c|c|c|}
\hline \multirow[t]{8}{*}{ Record Sources } & & & \multicolumn{3}{|l|}{ record modality } \\
\hline & & & verbal & \multicolumn{2}{|l|}{ visual } \\
\hline & record type & graphic & verbal text & \multicolumn{2}{|l|}{ picture } \\
\hline & & record & symbolic text & \multicolumn{2}{|l|}{ diagram } \\
\hline & & recording & audio recording & \multicolumn{2}{|c|}{ video recording } \\
\hline & record access & individual & & & \\
\hline & & shared & \multicolumn{3}{|l|}{ display } \\
\hline & & & \multicolumn{3}{|l|}{ copy } \\
\hline \multirow[t]{12}{*}{ Record Sourcing } & sourcing mode & restate & repeat & \multicolumn{2}{|c|}{ e.g. read aloud } \\
\hline & & & diverge & \multicolumn{2}{|c|}{ summarise } \\
\hline & & & & \multicolumn{2}{|c|}{ rephrase } \\
\hline & & & & \multicolumn{2}{|l|}{ recast } \\
\hline & & indicate & pointing & verbal & locate \\
\hline & & & & gesture & point \\
\hline & & & describing & \multirow[t]{2}{*}{ verbal } & compare \\
\hline & & & & & class/part \\
\hline & & & & \multirow[t]{2}{*}{ gesture } & imitate \\
\hline & & & & & symbolize \\
\hline & sourcing & same as record & & & \\
\hline & language & other language & & & \\
\hline
\end{tabular}

Table 18 Spoken sources

\begin{tabular}{lll}
\hline Spoken Sources & individual knowledge & teacher knowledge \\
& learner knowledge & \\
shared knowledge & prior lesson & \\
prior move & new \\
Spoken Sourcing & present & restate \\
& & remind \\
& elicit & enquire \\
& & \\
\end{tabular}

Table 19 Recording

\begin{tabular}{|c|c|c|c|c|}
\hline \multirow[t]{4}{*}{ Write } & \multirow{4}{*}{ writing type } & \multirow{4}{*}{ write text } & \multicolumn{2}{|l|}{ writing mode } \\
\hline & & & wordings & symbols \\
\hline & & & constructed text & equation \\
\hline & & & notes & expression \\
\hline & & annotate & & \\
\hline \multirow[t]{3}{*}{ Draw } & picture & & & \\
\hline & diagram & & & \\
\hline & mark record & & & \\
\hline
\end{tabular}


Table 20 Acts \& interacts

\begin{tabular}{|c|c|c|c|c|c|c|c|}
\hline \multirow[t]{19}{*}{ Interacts } & \multirow[t]{13}{*}{ teacher roles } & \multirow[t]{10}{*}{ instructing } & \multirow{10}{*}{$\begin{array}{l}\text { presenting } \\
\text { knowledge } \\
\text { evaluating } \\
\text { learners }\end{array}$} & \multicolumn{4}{|l|}{ model } \\
\hline & & & & \multirow{2}{*}{\multicolumn{4}{|c|}{$\begin{array}{l}\text { impart } \\
\text { check (before evaluating) }\end{array}$}} \\
\hline & & & & & & & \\
\hline & & & & evaluate & affirm & repeat & \\
\hline & & & & & & approve & \\
\hline & & & & & & praise & \\
\hline & & & & & reject & implicit & qualify \\
\hline & & & & & & & ignore \\
\hline & & & & & & explicit & negate \\
\hline & & & & & & & admonish \\
\hline & & directing & direct & & & & \\
\hline & & & suggest & & & & \\
\hline & & & permit & & & & \\
\hline & learner roles & display & (for evaluation) & & & & \\
\hline & & accord & concur $^{a}$ & & & & \\
\hline & & & demur & & & & \\
\hline & teacher/learner & invite & & & & & \\
\hline & roles & inquire & & & & & \\
\hline & & insist & & & & & \\
\hline \multirow[t]{15}{*}{ Acts } & behaviouralacts & learners & behaviour & & & & \\
\hline & & & display & & & & \\
\hline & & & accordance & & & & \\
\hline & & teacher & evaluation & & & & \\
\hline & & teacher/learners & activity & & & & \\
\hline & conscious acts & perceptive & attention & & & & \\
\hline & & & perception & & & & \\
\hline & & & reception & & & & \\
\hline & & cognitive & knowledge & & & & \\
\hline & & & choice & & & & \\
\hline & & & reasoning & & & & \\
\hline & & & conception & & & & \\
\hline & & affective & attitude & & & & \\
\hline & & & engagement & & & & \\
\hline & & & anticipation & & & & \\
\hline
\end{tabular}

aLearners have options to concur or demur from teachers' or learners' acts, whereas teachers have the institutional authority to evaluate learner acts by affirming or rejecting (Bernstein 1990, Rose 2018a)

\section{Abbreviations}

A1: Primary actor; A1f: Primary actor follow-up; A2: Secondary actor; A2f: Secondary actor follow-up; dA1: Delayed primary actor; dK1: Delayed primary knower; K1: Primary knower; K1f: Primary knower follow up; K2f: Secondary knower follow up; K2: Secondary knower

\section{Availability of data and materials}

Please contact authors for data requests.

\section{Authors' contributions}

HK carried out the project, collected and analyzed the data, and drafted the manuscript. DR analyzed the data and drafted the manuscript. Both authors read and approved the final manuscript. 


\section{Competing interests}

The authors declare that they have no competing interests.

\section{Publisher's Note}

Springer Nature remains neutral with regard to jurisdictional claims in published maps and institutional affiliations.

\section{Author details}

${ }^{1}$ Department of Curriculum and Instruction, Faculty of Education, Chinese University of Hong Kong, Ma Liu Shui, Hong Kong. ${ }^{2}$ Hong Kong, Hong Kong SAR. ${ }^{3}$ Department of Linguistics, University of Sydney, Camperdown, NSW, Australia.

Received: 24 April 2018 Accepted: 2 August 2018

Published online: 22 August 2018

\section{References}

Bernstein, B. 1990. Class. Codes and control IV: The structuring of pedagogic discourse. London: Routledge.

Bernstein, B. 2000. Pedagogy, Symbolic Control and Identity: theory, research, critique. London \& Bristol, PA: Taylor \& Francis (revised edition Lanham, Maryland: Rowan \& Littlefield.).

Canagarajah, A. 2011. Translanguaging in the classroom: Emerging issues for research and pedagogy. Applied Linguistics Review 2: 1-28.

Cenoz, J., F. Genesee, and D. Gorter. 2014. Critical analysis of CLIL: Taking stock and looking forward. Applied Linguistics 35 (3): $243-262$.

Christie, F. 2002. Classroom discourse analysis. London, New York: Continuum.

Coyle, D., P. Hood, and D. Marsh. 2010. CLIL: Content and language integrated learning. Cambridge: Cambridge University Press.

Creese, A., and A. Blackledge. 2010. Translanguaging in the bilingual classroom: A pedagogy for learning and teaching? The Modern Language Journal 94 (1): 103-115.

Cummins, J. 2014. Rethinking pedagogical assumptions in Canadian French immersion programs. Journal of Immersion and Content-Based Language Education 2 (1): 3-22. https://doi.org/10.1075/jicb.2.1.01cum.

Garcia, O., and Li Wei. 2014. Translanguaging: Lanquage, bilingualism and education. London: Palgrave Macmillan.

Halliday, M.A.K. 1978. Language as a social semiotic: The social interpretation of language and meaning. London: Arnold.

Howatt, A. 1984. A history of English language teaching. Oxford: Oxford University Press.

Kartika-Ningsih, H. 2016. Multilingual re-instantiation: Genre pedagogy in Indonesian classrooms. PhD thesis: Sydney University http://www.isfla.org/Systemics/Print/Theses/HKartika-Ningsih_thesis.pdf.

Lambert, W.E. 1984. An overview of issues in immersion education. In California State Department of Education (Ed.), Studies on immersion education: A collection for United States educators (pp. 8-30). Sacramento: California State Department of Education.

Levine, G.S. 2011. Code choice in the language classrooms. Bristol: Multilingual Matters

Lin, A. 2013. Classroom code-switching: Three decades of research. Applied Linguistics Review 4 (1): 195-218 http://hdl. handle.net/10722/184270.

Lin, A. 2015. Conceptualising the potential role of L1 in CLIL. Lanquage, Culture and Curriculum 28 (1): 74-89. https://doi. org/10.1080/07908318.2014.1000926.

Martin, J. 1992. English text: System and structure. Philadephia/Amsterdam: John Benjamins Publishing Company.

Martin, J.R., and D. Rose. 2007. Working with discourse: Meaning beyond the clause. London: Continuum.

Martin, J.R., and D. Rose. 2008. Genre relations: Mapping culture. London: Equinox.

Maton, K. 2013. Knowledge and knowers: Towards a realist sociology of education. London: Routledge.

Montolalu, L.R., and L. Suryadinata. 2007. National language and nation-building: The case of Bahasa Indonesia. In Language nation and development, ed. L.H. Guan and L. Suryadinata, 39-50. Singapore: Institute of Southeast Asian Studies.

Rose, D. 2014. Analysing pedagogic discourse: an approach from genre and register. Functional Linguistics, 1:11, http:// www.functionallinguistics.com/content/1/1/11, https://functionallinguistics.springeropen.com/articles/10.1186/ s40554-014-0011-4

Rose, D. 2018a. Pedagogic register analysis: Mapping choices in teaching and learning. Functional Linguistics 5: 3 Springer Open Access, http://rdcu.be/HD9G.

Rose, D. 2018b. Reading to Learn: Accelerating learning and closing the gap, Teacher training books and DVDs. Sydney: Reading to Learn http://www.readingtolearn.com.au.

Rose, D., and J. Martin. 2014. Intervening in contexts of schooling. In Discourse in Context: Contemporary Applied Linguistics, ed. J. Flowerdew and Li Wei, vol. 3, 273-300. London: Bloomsbury Academic.

Rose, D., and J.R. Martin. 2012. Learning to write, reading to learn: Genre, knowledge and pedagogy in the Sydney school. South Yorkshire/Bristol: Equinox Publishing.

Sneddon, J.N. 2003. The Indonesian lanquage: Its history and role in modern society. Sydney NSW: University of New South Wales Ltd.

Yu, W. 2000. Direct method. In M. Byram (Ed.), Routledge encyclopedia of language teaching and learning (pp. 176178). New York: Routledge. 